\title{
What Method of Learning do Media Students Prefer at Lectures: Auditory or Visual?
}

\author{
Valery Okulich-Kazarin \\ School of Entrepreneurship, Wroclaw University of Environmental and Life Sciences, Wroclaw, Poland
}

Received January 29, 2020; Revised February 21, 2020; Accepted April 7, 2020

Copyright $\bigcirc 2020$ by author, all rights reserved. Author agrees that this article remains permanently open access under the terms of the Creative Commons Attribution License 4.0 International License

\begin{abstract}
The goal of the study was to know what method of learning do media students prefer at lectures: auditory or visual? The main methods of the study were information research, methods of sociological research, social statistics and verification of statistical hypotheses. More than 200 scientific sources on this topic were studied, including those published in journals indexed in databases WoS and SCOPUS. The practical part of the study was focused locally, in Russia, Lithuania and Poland. The author tried to ensure maximum diversity of Respondent groups. It is the first time that independent media student opinions were transformed into new scientific knowledge. It was statistically proved that the media students do not prefer the auditory method of learning at lectures. The media students prefer the visual method of learning at lectures. So the results have a great practical and scientific importance: 1 . university teachers should use visual methods for teaching media students at lectures; 2. it should be taken into account to correct the learning theory for teaching media students at lectures. The results are highly statistically significant (99.0\%). We have a decision-making process with accurate, controlled probability.
\end{abstract}

Keywords Media Students, Student Preferences, Lectures, Method of Learning, Auditory Method, Visual Method

\section{Introduction}

The use of social media entering our lives through Web 2.0 technology reaches wide audiences [1]. Social media has been gaining a foothold in education [2]. Students use social media to complete homework-related tasks and maintain friendship [3]. The objects of modern media are traditional and new areas of media: mass media, mass communications, journalism, advertising, public relations, social networks, new media, blogs, live magazines, feedback and commenting on messages by users on the Network [4].

Teachers also use social media to create an alternative platform of instruction $[5,6]$ and build professional learning communities [7]. It is possible to say that the social media and media literacy courses that the social studies teacher candidates have during their undergraduate studies have an effect on their awareness of media [1].

Media students are at the forefront of learning using social and other media tools. Therefore, it is very important and interesting to study preferences of future media professionals associated to method of learning at lectures.

\section{Metods}

\subsection{General Information}

The study was carried out by the Head of East European Scientific Group since May 2018 till November 2019. When planning an ascertaining experiment, the author has relied on the results of previous studies. The practical part of the study was focused locally, in Russia, Lithuania and Poland. From a theoretical point of view, the author relied on studies carried out in the World before that.

The goal of the study was to know what method of learning do media students prefer at lectures: auditory or visual?

It was used the methods of sociological research [8]. For statistical calculations it was used the methods of social statistics [9].

The object of the study is educational services of media students at lectures.

The subject of the study is two methods of learning media students at lectures: auditory and visual.

The Research hypothesis: media students prefer the auditory learning method at lectures. 
The study was performed in several stages:

- literature review;

- $\quad$ planning the ascertaining experiment;

- $\quad$ primary processing and grouping of results;

- $\quad$ statistical verification of the diversity of Respondent groups;

- $\quad$ statistical observation and verification of statistical hypotheses [10];

- drawing the conclusions and writing the text.

\subsection{Primary Processing and Grouping of Results}

This was used serial (nested) sampling [9] for the ascertaining experiment. Serial (nested) sampling assumes that the series or groups of units of the population are to be selected. In our study, the series were selected randomly. Then continuous observation was carried out in each selected series. The author tried to ensure maximum diversity of Respondent groups.

The plan of the ascertaining experiment included a comparison in four pairs:

- media students of Full-time and Part-time forms of training,

- $\quad$ media students of 1 and 2 levels (bachelor study and master study),

- media students of first year and last year of training,

- media students of the capital city and of the non-capital city.

The plan of the ascertaining experiment is presented in Table 1.
Table 1. The plan of the ascertaining experiment

\begin{tabular}{|c|c|c|c|c|}
\hline $\mathrm{Nr}$ & The diversity criterion & Russia & Lithuania & Poland \\
\hline 1 & Full-time & + & + & + \\
\hline 2 & Part-time & - & + & - \\
\hline 3 & Bachelor study, 1 year & - & + & - \\
\hline 4 & Bachelor study, 4 year & + & - & - \\
\hline 5 & Master study, 1 year & + & - & - \\
\hline 6 & Master study, 2 year & - & - & + \\
\hline 7 & Students of the capital city & + & + & - \\
\hline 8 & $\begin{array}{c}\text { Students of the non-capital } \\
\text { city }\end{array}$ & - & - & + \\
\hline
\end{tabular}

Table 1 shows that groups of each countries surveyed met at least three diversity criteria. The characteristics of the respondents are presented in Table 2.

In total, 72 respondents from Russia, Lithuania and Poland took part in the statistical observation.

Then one-time statistical observation was organized [9]. The purpose of statistical observation is to obtain reliable information to identify the preferences related the method of learning at lectures in the study population. Statistical observation was a one-time event, organized in Russia, Lithuania and Poland.

In our statistical observation we used the method of survey. According to the method of obtaining data, it was a method of self-registration, in which the respondents gave the necessary information, independently filling out pre-distributed registration forms.

Table 2. General characteristics of the media Respondents

\begin{tabular}{|c|c|c|c|c|}
\hline $\mathrm{Nr}$ & Speciality and level & $\begin{array}{l}\text { Amount, } \\
\mathrm{M}|\mathrm{F}| \mathrm{N} / \mathrm{a}\end{array}$ & $\begin{array}{l}\text { Training } \\
\text { form }\end{array}$ & University \\
\hline 1 & Journalism, bachelor students, 4 year & $\begin{array}{c}21 \\
(4|11| 6) \\
\end{array}$ & full-time & \multirow{2}{*}{$\begin{array}{l}\text { Moscow Pedagogical State } \\
\text { University, Russia }\end{array}$} \\
\hline 2 & $\begin{array}{c}\text { Theory and practice of international communication, master } \\
\text { students, } 1 \text { year }\end{array}$ & $\begin{array}{c}8 \\
(0|5| 3)\end{array}$ & full-time & \\
\hline 3 & Visual design and media, bachelor students, 1-4 year & $\begin{array}{c}18 \\
(0|15| 3)\end{array}$ & part-time & \multirow{2}{*}{$\begin{array}{c}\text { European humanities University, } \\
\text { Lithuania }\end{array}$} \\
\hline 4 & Media and communication, bachelor students, 1 year & $\begin{array}{c}15 \\
(4|9| 2) \\
\end{array}$ & full-time & \\
\hline \multirow[t]{2}{*}{5} & Media and cultural studies, master students, 2 year & $\begin{array}{c}10 \\
(0|8| 2)\end{array}$ & full-time & $\begin{array}{c}\text { Pedagogical University of Cracow, } \\
\text { Poland }\end{array}$ \\
\hline & Total number of respondents: & $\begin{array}{c}72 \\
(8|48| 16)\end{array}$ & - & - \\
\hline
\end{tabular}


The registration form was created by author. The registration form contained 9 questions (app.). The main question was:

- What method of learning do I prefer at lectures?

Three possible answers were provided:

1. The teacher has a presentation, and I write from slides.

2. The teacher dictates, and I write.

3. The teacher quickly tells, and I note.

The first variant of the answer refers to the visual method of teaching at lectures. The second and third answers relate to the auditory method of teaching at lectures. So, in our observation attribute features were studied [9]. Further, attribute features were converted to numeric values. The study used the second group of methodological techniques and statistical indicators, combined on the basis of the unity of cognitive functions and calculation algorithms [10]. And, at last, after discussion of the received results, author has made the conclusion.

\section{Literature Review}

The description of the state of research in this field was made. More than 200 scientific sources were studied, including those published in the journals: European Journal of Contemporary Education, European Journal of Higher Education, Higher Education, Higher Education in Europe, Higher Education Pedagogies, International Journal for Academic Development, International Journal of Education and Practice, Journal of Higher Education Policy and Management, Journal of Marketing for Higher Education, Media Education (Mediaobrazovanie), Research in Higher Education, Studies in Higher Education, Universal Journal of Educational Research, etc. The papers that are the closest to the topic of the study were selected for a thorough analysis later, including above 10 papers in journals indexed in databases Web of Science and SCOPUS.

According the learning theory $[11,12]$, a lecture is one of the main forms of the educational process and the main way of teaching at the university. Lectures appeared in the practice of teaching in ancient Greece and other ancient states. Then they received wide circulation in medieval universities and retained their leading role in higher education to the present day.

There are two alternative methods of teaching at lectures - auditory and visual. The analysis of scientific works on the learning theory showed that for several hundred years the auditory method of teaching dominated at lectures. And today, of the nine approaches of teaching at lectures, seven approaches refer to the auditory method and two refer to the visual one [13].

The auditory teaching style allows auditory students to learn by ear or through verbal communication [14]. The aim of the work [15] was to evaluate the views of students on auditory learning and learning strategy for the interactive and communicative classroom environment. The students' opinions, obtained during the interviews, show that their skills, attitude and predisposition to auditory learning style are significant and determining factors for effective teaching.

Visual education is a style in which a student uses graphs, diagrams, maps and diagrams. The article [16] introduces a new concept for enhancing students' analytical thinking skills based on visual learning strategies. The author's results showed that visual learning tools enhance the students' skills.

Modern social media has been widely using in education process [2]. For example, students use social media to complete homework-related tasks [3]. The author suggests that media students should prefer a visual method of learning.

There are many papers describing the study of the learning process of media students [4, p. 278-285; 17-21; etc.). However, these studies did not address preferences of media students at lectures.

Understanding how audiences differ in their preferences are starting points for identifying what is a prerequisite to having data-informed conversations and decisions [22].

The literature review on the learning theory shows that the auditory method of teaching dominates at lectures. At the same time, it was not shown which method of learning do media students prefer. Therefore, it is possible that there is a contradiction between the auditory way of teaching at lectures and preferences of media students.

Therefore, next we will focus on the study of preferences of media students in lectures. The goal of the research was to know what method of learning do media students prefer at lectures: auditory or visual?

\section{Results}

\subsection{Primary Processing and Grouping of Monitoring Results}

The results of the determining the average values and the variation of the characteristics are given in Table 3. The main question of the registration form was: What method of learning do I prefer at lectures?

Three possible answers were provided:

1. The teacher has a presentation, and I write from slides.

2. The teacher dictates, and I write the lecture.

3. The teacher quickly tells, and I note.

For the determining the average values and the variation of the characteristics, the value " 0 " was assigned to the auditory method of learning. Answers No. 2 and No. 3 relate to the auditory method of learning at the lectures. So, they were combined before the calculation. The value "1" was assigned to the visual method of learning 
Table 3. The average values and the variation of the characteristics (number of variants of different answers)

\begin{tabular}{|c|c|c|c|c|c|c|c|}
\hline \multirow[b]{2}{*}{ No } & \multirow[b]{2}{*}{ Speciality and level } & \multicolumn{3}{|c|}{ The number of choices } & \multirow[b]{2}{*}{$\dot{\mathrm{X}}$} & \multirow[b]{2}{*}{$\delta_{\mathrm{x}}$} & \multirow[b]{2}{*}{$\delta_{\mathrm{x}-1}$} \\
\hline & & $\begin{array}{c}\text { response } \\
1 \\
\end{array}$ & $\begin{array}{c}\text { response } \\
2 \\
\end{array}$ & $\begin{array}{c}\text { response } \\
3 \\
\end{array}$ & & & \\
\hline 1 & Journalism, bachelor students, 4 year & 12 & 2 & 7 & 0.57 & 0.49 & 0.51 \\
\hline 2 & $\begin{array}{c}\text { Theory and practice of international communication, master } \\
\text { students, } 1 \text { year }\end{array}$ & 6 & 2 & 0 & 0.75 & 0.43 & 0.46 \\
\hline 3 & Visual design and media, bachelor students, 1-4 year & 14 & 0 & 4 & 0.78 & 0.41 & 0.43 \\
\hline 4 & Media and communication, bachelor students, 1 year & 12 & 1 & 2 & 0.80 & 0.40 & 0.41 \\
\hline 5 & Media and cultural studies, master students, 2 year & 10 & 0 & 0 & 1.00 & 0.00 & 0.00 \\
\hline \multirow[t]{2}{*}{6} & Total number of responses & 54 & 5 & 13 & 0.75 & 0.43 & 0.44 \\
\hline & The value for statistics & 1 & \multicolumn{2}{|c|}{0} & - & - & - \\
\hline
\end{tabular}

The table 3 shows the total results of the initial assessment of respondents' preferences when they receive information at the lectures.

The comparison results are shown in Figure 1. Here are the preferences of the media students. It was 72 Respondents in total.

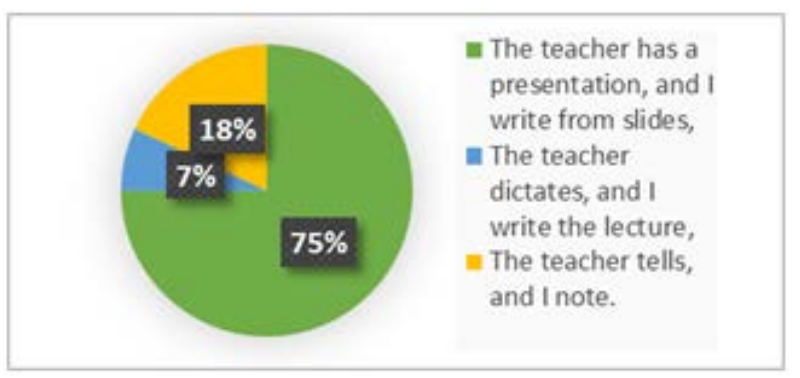

Figure 1. The number of choices of the learning method at lectures, \%

Figure 1 shows that the visual learning method dominates at the preferences of the media students. It is shown that the auditory learning method does not dominate in pedagogical practice. In this situation, table 2 is not a basis for strong evidence. So, the author made a verification of statistical hypotheses.

\subsection{Statistical Verification of the Diversity of Respondent Groups}

The F-test was used for the verifcation of statistical hypotheses. This test is based on F-statistics, which represents the ratio of two variances [23, p.3-11]. In the study, the following assumptions for one-way ANOVA were adopted:

1) The dataset consists of 5 random samples of 5 general populations.

2) All the general populations had a normal distribution. Additionally, the standard deviations of the populations were identical. That is, $S_{1}=S_{2}=S_{3}=S_{4}=S_{5}$. This allows for the use of the standard statistical tables for hypothesis testing.

The results of verification of statistical hypotheses that all five groups of respondents belong to one General population of media students are presented below [9, 23].

The Research hypothesis $\mathrm{H}_{0}: \dot{\mathrm{X}}_{\mathrm{i}}=\dot{\mathrm{X}}_{\mathrm{j}}$ (the means are all equal).

The Research hypothesis claims that the means of the five populations are equal. In other words, the difference of means is the result of random fluctuations.

The Alternative hypothesis $\mathrm{H}_{1}: \dot{\mathrm{X}}_{\mathrm{i}} \neq \dot{\mathrm{X}}_{\mathrm{j}}$ (the means are not all equal at least for one pair of variances).

The Alternative hypothesis claims that the means of the five populations are not equal. In other words, the difference of means is not the result of random fluctuations.

Further calculation includes number of the General populations (number of occupational groups), $\mathrm{k}=5$ (five). The total sample size is represented as follows (table 3, lines 1-5):

$$
\mathrm{n}=\mathrm{n}_{1}+\mathrm{n}_{2}+\mathrm{n}_{3}+\mathrm{n}_{4}+\mathrm{n}_{5},
$$

$\mathrm{n}=21+8+18+15+10=72$ respondents.

The grand average of the 5 samples $\dot{X}$ [23, 3-11]:

$$
\begin{gathered}
\dot{\mathrm{X}}=\left(\mathrm{n}_{1} \times \dot{\mathrm{X}}_{1}+\mathrm{n}_{2} \times \dot{\mathrm{X}}_{2}+\mathrm{n}_{3} \times \dot{\mathrm{X}}_{3}+\mathrm{n}_{4} \times \dot{\mathrm{X}}_{4}+\mathrm{n}_{5} \times \dot{\mathrm{X}}_{5}\right) / \mathrm{n}, \\
\dot{\mathrm{X}}=(21 \times 0.57+8 \times 0.75+18 \times 0.78+15 \times 0.80+ \\
10 \times 1.00) / 72=0.75 .
\end{gathered}
$$

The number of degrees of freedom are here: $\mathrm{k}-1=4$. The between-sample variability for one-way analysis of variance $\overline{\mathrm{G}}$ :

$$
\begin{gathered}
\overline{\mathrm{G}}=\left[\mathrm{n}_{1} \times\left(\dot{\mathrm{X}}_{1}-\dot{\mathrm{X}}\right)^{2}+\mathrm{n}_{2} \times\left(\dot{\mathrm{X}}_{2}-\dot{\mathrm{X}}\right)^{2}+\mathrm{n}_{3} \times\left(\dot{\mathrm{X}}_{3}-\dot{\mathrm{X}}\right)^{2}+\mathrm{n}_{4} \times\left(\dot{\mathrm{X}}_{4}\right.\right. \\
\left.-\dot{\mathrm{X}})^{2}+\mathrm{n}_{5} \times\left(\dot{\mathrm{X}}_{5}-\dot{\mathrm{X}}\right)^{2}\right] /(\mathrm{k}-1), \\
\overline{\mathrm{G}}=(1.39) / 4=0.348
\end{gathered}
$$

The degrees of freedom are indicated by $\mathrm{n}-\mathrm{k}=72-4$ $=68$ (for the within-sample variability).

The following is the within-sample variability for one-way analysis of variance $\dot{\mathrm{S}}$ :

$$
\begin{gathered}
\dot{\mathrm{S}}=\left[\left(\mathrm{n}_{1}-1\right) \times\left(\mathrm{S}_{1}\right)^{2}+\left(\mathrm{n}_{2}-1\right) \times\left(\mathrm{S}_{2}\right)^{2}+\left(\mathrm{n}_{3}-1\right) \times\left(\mathrm{S}_{3}\right)^{2}+\right. \\
\left.+\left(\mathrm{n}_{4}-1\right) \times\left(\mathrm{S}_{4}\right)^{2}+\left(\mathrm{n}_{5}-1\right) \times\left(\mathrm{S}_{5}\right)^{2}\right] /(\mathrm{n}-\mathrm{k}), \\
\dot{\mathrm{S}}=1.43 / 68=0.021
\end{gathered}
$$

F-statistics are indicating the extent to which the sample averages differ one from another (the numerator) with 
respect to the overall level of variability in the samples (the denominator). F-statistics for one-way ANOVA are indicated as follows:

$$
\begin{gathered}
\mathrm{F}=\overline{\mathrm{G}} / \dot{\mathrm{S}}, \\
\text { F-statistics }=0.348 / 0.021=16.571 .
\end{gathered}
$$

\subsection{The Result of the F-test}

The F-table critical value is 3.649 at the level of hypothesis testing $99.0 \%$ [23, p.3-11]. To verify the Research hypothesis the F-statistic (16.571) was compared to the F-table critical value (3.649) at the level of hypothesis testing $99.0 \%$. Since the F-statistic is larger there is no reason to accept the Research hypothesis. The Alternative hypothesis was accepted: the means of the five populations are not equal. That is, all five population groups are not identical. The Alternative hypothesis was accepted. This result is stronger compared to the case when the Research hypothesis is accepted.

The results were accepted for the standard significance level of 99.0\%. It means that the solution will be correct approximately in $99.0 \%$ of cases and incorrect only in $1.0 \%$ of cases [10, p.75]. We have a decision-making process with accurate, controlled probability.

Thus, the diversity of Respondent groups was secured. The high statistical significance (99.0\%) of the result frees us from questioning additional groups of respondents.

\subsection{Verification of Statistical Hypotheses for Determining Students' Preferences: Media Students Prefer the Auditory Learning Method at Lectures}

At this stage of verification of statistical hypotheses, two alternatives were considered [10]. Each of them has a pair of statistical hypotheses. There are a Research hypothesis and an Alternative hypothesis.

1. Media students prefer the auditory learning method at lectures.

The Research hypothesis: media students prefer the auditory learning method at lectures.

The Research hypothesis $\mathrm{H}_{0}: \mu=0.0$.

The Research hypothesis is as follows: media students prefer the auditory learning method at lectures, if one does not take into account random deviations.

The Alternative hypothesis: media students do not prefer the auditory learning method at lectures.

The Alternative hypothesis $\mathrm{H}_{1}: \mu \neq 0.0$.

The Alternative hypothesis is as follows: media students do not prefer the auditory learning method, if one does not take into account random deviations.

2. Media students prefer the visual learning method at lectures.

The Research hypothesis: media students prefer the visual learning method at lectures.

The Research hypothesis $\mathrm{H}_{0}: \mu=1.0$.
The Research hypothesis is as follows: media students prefer the visual learning method at lectures, if one does not take into account random deviations.

The Alternative hypothesis: media students do not prefer the visual learning method at lectures.

The Alternative hypothesis $\mathrm{H}_{1}: \mu \neq 1.0$.

The Alternative hypothesis is as follows: media students do not prefer the visual learning method, if one does not take into account random deviations.

Table 4 shows the results for verification of statistical hypotheses at $\mu_{0}=0.0$ and at $\mu=1.0$ for the data from table 3 (line 6).

Table 4. Data for verification of statistical hypotheses

\begin{tabular}{|c|c|c|}
\hline No & Indicator & Result \\
\hline 1 & Sample size, $\mathrm{n}$ & 72 \\
\hline 2 & Selective average, $\dot{\mathrm{X}}$ & 0.75 \\
\hline 3 & Standard deviation for the sample, $\delta_{\mathrm{x}}$ & 0.43 \\
\hline 4 & Average error, $\dot{\mathrm{S}}_{\dot{\mathrm{X}}}=\delta_{\mathrm{x}} / \sqrt{\mathrm{n}}$ & 0.118 \\
\hline 5 & Value $\left|\mathrm{t}_{\text {stat }}\right|$ for $\mu_{0}=0.0,\left(\dot{\mathrm{X}}-\mu_{0}\right) / \dot{\mathrm{S}}_{\dot{\mathrm{X}}}$ & 6.356 \\
\hline 6 & Value $\left|\mathrm{t}_{\text {stat }}\right|$ for $\mu_{0}=1.0,\left(\dot{\mathrm{X}}-\mu_{0}\right) / \dot{\mathrm{S}}_{\dot{\mathrm{X}}}$ & 2.120 \\
\hline 7 & Value $\mathrm{t}_{\text {tabl }}$ for significance level $99.0, \%[10, \mathrm{p} .42]$ & 2.576 \\
\hline 8 & Result for $\mu_{0}=0.0, \mathrm{t}_{\text {stat }}>\mathrm{t}_{\text {tabl }}$ & Yes \\
\hline 9 & Result for $\mu_{0}=1.0, \mathrm{t}_{\text {stat }}>\mathrm{t}_{\text {tabl }}$ & No \\
\hline
\end{tabular}

Table 4 shows that the $t_{\text {stat }}$ value for $\mu_{0}=0.0$ is greater than the $t_{\text {tabl }}$ value for the $99.0 \%$ significance level (lines 5 and 8). Therefore, we accept the Alternative hypothesis: the unknown average for the general population of students $\mu \neq 0.0$. This means that media students do not prefer the auditory learning method at lectures, if one does not take into account random deviations. The Alternative hypothesis was accepted. This result is stronger compared to the case when the Research hypothesis is accepted.

At the same time, table 4 shows that the $t_{\text {stat }}$ value for $\mu_{0}$ $=1.0$ is not greater than the $t_{\text {tabl }}$ value for the $99.0 \%$ significance level (lines 6 and 9). Therefore, we accept the Research hypothesis: the unknown average for the general population of students $\mu=1.0$. This means that media students prefer the visual method of learning at lectures, if one does not take into account random deviations.

This means that university teachers and professors should use visual methods of lectures more widely.

\section{Discussion}

Are 72 respondents enough or not enough? In the paper [15], the study was carried out only with the participation of 15 university students. Next, in the paper [24] the study was carried out only with the participation of 40 respondents. And, in the paper [25] there were 48 students only. So, we are sure 72 students are sufficient to get a reliable result in the study.

And finally, at the step of verification of statistical 
hypotheses about the preferred learning method at lectures, the results were accepted for the standard significance level of $99.0 \%$. It shows that the solutions will be correct approximately in $99.0 \%$ of cases and incorrect only in $1.0 \%$ of cases. We have a decision-making process with accurate, controlled probability. The theory of statistics does not give reason to doubt the correctness of the results. It frees the author to prove the correctness of the results [10].

\section{Conclusions}

It was studied the preferences of media students related the learning method at lectures. The goal of the study is achieved. It is the first time that independent media student opinions were transformed into new scientific knowledge.

1. It was statistically proved that the media students do not prefer the auditory learning method which dominates at lectures. It was statistically proved that the media students prefer the visual learning method at lectures.

2. The results are not a new scientific Law, a new scientific conception, a new theory. The results are new scientific facts. These new scientific facts should be taken into account to correct the learning theory for teaching media students at lectures.

3. The results of the study have a great practical importance. The systems of teaching media students cannot ignore the preferences of media students who does not prefer the auditory learning method at lectures. On the basis of new scientific facts about the media student preferences the real recommendation could been given: university teachers should use visual method for teaching media students at lectures.

4. The task of the next study is to study in detail the preferences of media students in West European countries.

\section{Appendix}

\section{Questionnaire}

The questionnaire is completely anonymous. Date of completion

\begin{tabular}{|l|l|l|l|l|}
\hline Country and city: & \multicolumn{4}{|l|}{} \\
\hline Name of the University (school): & \multicolumn{4}{|l|}{} \\
\hline Specialty, course of study: & \multicolumn{3}{|l|}{} & refuse to answer \\
\hline Gender (underline, please): & Male & Female & Transgender & \\
\hline
\end{tabular}

Please write down your answers regarding the last 2-3 semesters.

Your answers will help us to make learning more effective and enjoyable.

\begin{tabular}{|c|c|c|c|}
\hline 1. I like to study (underline, please): & \multicolumn{2}{|c|}{ YES } & NO \\
\hline 2. I like to write term papers and presentations (underline, please): & \multicolumn{2}{|c|}{ YES } & NO \\
\hline 3. I like to take exams (underline, please): & \multicolumn{2}{|c|}{ YES } & NO \\
\hline 4a. I prefer to take exams (underline, please, only one option): & in the oral form & $\begin{array}{l}\text { in the written } \\
\text { form }\end{array}$ & in the form of a test \\
\hline $\begin{array}{l}\text { 4б. If you prefer exams in the form of test, what option do you prefer } \\
\text { exactly (underline, please, only one option): }\end{array}$ & $\begin{array}{l}\text { with open } \\
\text { answers }\end{array}$ & $\begin{array}{l}\text { with closed } \\
\text { answers and } \\
\text { single choice }\end{array}$ & $\begin{array}{l}\text { with closed answers } \\
\text { and multiple choice }\end{array}$ \\
\hline
\end{tabular}

5. What method of learning do I prefer at lectures? Underline, please, only one option:

- $\quad$ The lecturer has a presentation, and I write from slides.

- $\quad$ The lecturer dictates, and I write the lecture.

- $\quad$ The lecturer tells, and I note. 
6. What lecture method in availing educational services did the lecturers use (on average) - for the answer use, please, the numbers, $\%(0 ; 10 ; 20 ; 30 ; 40 ; 50 ; 60 ; 70 ; 80 ; 90 ; 100$, the sum should be $100 \%)$ :

\begin{tabular}{|l|c|c|c|c|c|}
\hline - The lecturer has a presentation, and students write with slides & & \\
\hline - The lecturer slowly dictates, and students write under dictation & $=100 \%$ \\
\hline - The lecturer quickly tells, and students write, that keep up & & \\
\hline the sum: & $0-20$ & $21-40$ & $41-60$ & $61-80$ & $81-100$ \\
\hline 7. I attend lectures on average (underline, please), \%: & 0 & $1-2$ & $3-5$ & & regular in semester \\
\hline 8. I prepare for exams (underline, please), days:
\end{tabular}
\begin{tabular}{|l|l|l|l|}
\hline 9. My favorite subjects of study are: \\
\hline
\end{tabular}

\section{Acknowledgements}

The study was carried out with the support of the scientific project: 02. Analysis of the effectiveness of educational processes on the basis of competencies and opinions of the participants of the educational process: innovations in the management of educational systems and processes.

The author is grateful for the time the participants gave in providing data. He also would like to thank reviewers for their insightful comments on improving of this manuscript.

\section{REFERENCES}

[1] H. Mertol, A. Alkan. Social Media Addiction of Social Studies and Class Teacher Candidates. Universal Journal of Educational Research, Vol. 7, No.7, 1537-1543, 2019.

[2] Y. Wang. U.S. State Education Agencies’ Use of Twitter: Mission Accomplished? SAGE Open, Volume: 6 issue: 1, 2016. https://doi.org/10.1177/2158244015626492

[3] S. Weeden, B. Cooke, M. McVey. Underage children and social networking. Journal of Research on Technology in Education, 45, 249-262, 2013.

[4] Y. Klyuev, et al. Teaching Future Journalists Media Research Methodology Using Digital Technologies. Media Education (Mediaobrazovanie), 2019, 59(2): 278-285, 2019.

[5] S. Aydin. A review of research on Facebook as an educational environment. Educational Technology Research \& Development, 60, 1093-1106, 2012.

[6] J. Kurtz. Twittering about learning: Using Twitter in an elementary school classroom. Horace, 25(1), 1-4, 2009.

[7] V. Cho, J. Ro, J. Littenberg-Tobias. What Twitter will and will not do: Theorizing about teachers' online professional communities. Learning Landscapes, 6(2), 45-62, 2013.

[8] A. I. Kravchenko. Sociologia: textbook for students. - M., Yurayt, 2014
[9] E. K. Vasileva, V. S. Lyalin. Statistika: textbook for students. - M., Yuniti-Dana, 2012.

[10] Textbook for the Program "Masters of Business Administration". BUS_9641_Business_Statistics_3, USA, NY, Kingston University, 2010.

[11] S. Samygin, Pedagogy and psychology of higher education. Series "Textbooks", Phoenix, Rostov-on-don, 1998.

[12] V. A. Slastenin, I. F. Isaev, A. I. Mishchenko, et al. Pedagogy: A manual for students of pedagogical education institutions. School Press, Moscow, 2000.

[13] V. Okulich-Kazarin, M. Zhurba, O. Pagava, et al. Lecture method preferences, auditory or visual, of Ukrainian consumers of educational services: a statistical analysis, International Journal of Education and Practice, Vol. 7, No.2, 54-65, 2019.

[14] J. Carnevale. Auditory Learners: Online available from https://study.com/academy/lesson/auditory-learners-definit ion-characteristics.html (03 May 2018).

[15] Fil. Kayalar, Fet. Kayalar. The effects of Auditory Learning Strategy on Learning Skills of Language Learners (Students' Views). IOSR Journal Of Humanities And Social Science (IOSR-JHSS), Volume 22, Issue 10, Ver. VII, 04-10, 2017.

[16] J. Raiyn. The Role of Visual Learning in Improving Students' High-Order Thinking Skills, Journal of Education and Practice, 7, 24, 115 - 121, 2016.

[17] S. V. Akmanova, L. V. Kurzaeva, N. A. Kopylova. The Factor Model of the Media Educational Concept of Developing Lifelong Self-learning Individual Readiness. Media Education (Mediaobrazovanie), 59(2): 185-193, 2019.

[18] D. D. N. N. Dissanayake. Challenges Faced by Journalism Education in Sri Lanka. Asia Pacific Media Educator, 28(2): 164-175, 2018.

[19] A. Fedorov, A. Levitskaya. Comparative analysis of the development of mass media education in the Commonwealth of Independent States (CIS) countries. Media Education (Mediaobrazovanie), 58(3): 39-62, 2018.

[20] A. Kothari, \& A. Hickerson. Social Media Use in Journalism Education: Faculty and Student Expectations. Journalism \& Mass Communication Educator, 71(4): 413-424, 2016. 
[21] J. Reyna, J. Hanham, \& P. C. Meier. A framework for digital media literacies for teaching and learning in higher education. E-Learning and Digital Media, 15(4): 176-190, 2018.

[22] C. Y. Alverson, S.H. Yamamoto. Educational Decision Making With Visual Data and Graphical Interpretation: Assessing the Effects of User Preference and Accuracy. SAGE Open, Volume: 6 issue: 4, 2016, https://doi.org/10.1177/2158244016678290.

[23] Textbook for the Program "Masters of Business Administration". BUS_9641_Business_Statistics_5M, USA, NY, Kingston University, 2009.

[24] C. Özdemir, E. D. Özdemir. Suggestions for Problems Faced in Basic Language Skills by University Students Learning Turkish in Kazakhstan. European Journal of Contemporary Education, 7(2), 344 - 359, 2018.

[25] A. Pavlova. Gendernaya asimmetria v oboznacheniykh socialnykh roley $\mathrm{v}$ russkom yazike $\mathrm{v}$ aspekte vospriyatiya. Przegląd Wschodnioeuropejski, VII/2, 211-221, 2016. 